\title{
Associations of selected bedding types with incidence rates of subclinical and clinical mastitis in primiparous Holstein dairy cows
}

\author{
R. F. Rowbotham ${ }^{*} \dagger^{1,2}$ and P. L. Ruegg* \\ *Department of Dairy Science, University of Wisconsin, Madison 53706 \\ †Grande Cheese Company, Brownsville, WI 53006
}

\begin{abstract}
The objective of this observational study was to determine the association of exposure to selected bedding types with incidence of subclinical (SM) and clinical mastitis (CM) in primiparous Holstein dairy cows housed in identical pens at a single facility. At parturition, primiparous cows were randomly assigned to pens containing freestalls with 1 of 4 bedding materials: (1) deep-bedded new sand (NES, $\mathrm{n}=27$ cows), (2) deep-bedded recycled sand (RS, $n=25$ cows), (3) deep-bedded manure solids (DBMS, $\mathrm{n}=31$ cows), and (4) shallow-bedded manure solids over foam-core mattresses (SBMS, $\mathrm{n}=26$ cows). For 12 mo, somatic cell counts of quarter milk samples were determined every $28 \mathrm{~d}$ and duplicate quarter milk samples were collected for microbiological analysis from all quarters with SM (defined as somatic cell count $>200,000$ cells $/ \mathrm{mL}$ ). During this period, duplicate quarter milk samples were also collected for microbial analysis from all cases of CM. For an additional $16 \mathrm{mo}$, cases of $\mathrm{CM}$ were recorded; however, no samples were collected. Quarter days at risk $(62,980)$ were distributed among bedding types and most quarters were enrolled for $>150 \mathrm{~d}$. Of 135 cases of SM, $63 \%$ resulted in nonsignificant growth and $87 \%$ of recovered pathogens $(n=33)$ were identified as coagulase-negative staphylococci. The distribution of etiologies of pathogens recovered from cases of SM was associated with bedding type. Coagulase-negative staphylococci were recovered from $12,38,11$, and $46 \%$ of quarters with SM from cows in pens containing NES, RS, DBMS, and SBMS, respectively. A result of nonsignificant growth was obtained for $81,59,89$, and $46 \%$ of quarters with SM from cows in pens containing NES, RS, DBMS, and SBMS, respectively. Quarters of primiparous cows bedded with NES tended to have greater survival time to incidence of $\mathrm{CM}$ than quarters of primiparous cows bedded with RS or DBMS.
\end{abstract}

Received November 23, 2015.

Accepted February 22, 2016.

${ }^{1} 630$ W. Madison St., Waterloo, WI 53594.

${ }^{2}$ Corresponding author: rob.rowbotham@grande.com
Key words: mastitis, dairy, environment, housing, bedding

\section{INTRODUCTION}

On modern dairy farms, most cases of clinical mastitis (CM) are caused by bacteria of environmental origin (Lago et al., 2011; Pinzón-Sánchez and Ruegg, 2011; Oliveira et al., 2013) and understanding and managing exposure of teats to bacteria in bedding materials is crucial to maintaining udder health (Hogan and Smith, 2012). Teats of dairy cattle may be in direct contact with bedding materials for 40 to $60 \%$ of the day (Tucker and Weary, 2004; Cook et al., 2005; Hogan and Smith, 2012), making bedding materials an important potential source of exposure to mastitis pathogens. Research has indicated that fresh and recycled sand and forestry byproducts (such as sawdust and wood shavings) are the most common types of bedding materials used on large Wisconsin dairy farms, but a small number of the largest herds use recycled manure products (Rowbotham and Ruegg, 2015). As compared with organic bedding materials, use of sand bedding has been associated with reduced exposure to bacteria (Fairchild et al., 1982; Hogan et al., 1989; Zdanowicz et al., 2004). Recycling bedding on-farm may provide economic opportunities for dairy producers. However, some recycled bedding materials (such as manure and recycled sand; Janzen et al., 1982; Hogan et al., 1989; Rowbotham, 2015) contain greater number of bacteria than numbers found in inorganic bedding (such as new sand). The greater numbers of bacteria in bedding have been associated with increased numbers of bacteria on teats of cows exposed to these materials (Zdanowicz et al., 2004).

The magnitude and type of exposure to bacteria has been associated with bedding type at this facility (Rowbotham, 2015). Large numbers of streptococci were recovered from new sand (NES), recycled sand (RS), deep-bedded manure solids (DBMS), and shallow-bedded manure solids over foam-core mattresses (SBMS) and on teats of cows housed on all 4 bedding types; however, the greatest numbers of bacteria were 
recovered from SBMS and on teats of cows bedded with RS and SBMS. In that portion of the study detailed in Rowbotham (2015), with the exception of DBMS (where numbers of gram-negative and streptococcal bacteria were similar), numbers of gram-negative bacteria in bedding were approximately 2 to $3 \log$ fewer than numbers of streptococci. Similarly, numbers of gramnegative bacteria were much less in NES and on teats of cows bedded with NES. A linear relationship between total rates of CM during lactation and the number of both total gram-negative bacteria and Klebsiella spp. in bedding was identified in a year-long observational study of 9 commercial dairy herds (Hogan et al., 1989). In another study, rates of new coliform IMI and numbers of coliform bacteria in recycled manure bedding were both greatest in the summer (Smith et al., 1985). Rendos et al. (1975) reported associations between the numbers of bacteria in bedding and recovered from teat skin, but also cautioned against extrapolation to explain rates of new IMI caused by these same bacteria. The authors stated that the relationship between bedding bacterial populations and mastitis needs to be investigated directly through a lengthy and controlled study of incidence of IMI of cows bedded with various materials. Two other studies failed to find associations between coliform bacterial numbers in bedding and coliform IMI (Natzke and LeClair, 1976; Fairchild et al., 1982); however, treatment groups contained only 3 to 10 cows and trial lengths were only 3 to 4 wk. The objective of this cohort study was to determine the association of exposure to 4 selected bedding types with incidence of subclinical mastitis (SM) and CM in primiparous Holstein dairy cows housed in identical pens at a single facility. The primary hypothesis was that exposure to different bedding types was associated with the occurrence of CM and SM.

\section{MATERIALS AND METHODS}

\section{Facility Design}

The study was conducted at the University of Wisconsin-Madison Marshfield Research Station. Four bedding types were tested in a freestall barn $29.3 \mathrm{~m}$ wide by $59.4 \mathrm{~m}$ long with 4.3 -m-tall open side walls that contained identical pens $(\mathrm{n}=4)$ each $11.3 \mathrm{~m}$ wide by $26.1 \mathrm{~m}$ long. Each pen of housed up to 32 lactating cows in 2 rows of 16 head-to-head freestalls. Freestall dimensions were $1.65 \mathrm{~m}$ from rear curb to brisket locator, $1.78 \mathrm{~m}$ from rear curb to neck rail, $0.23 \mathrm{~m}$ curb height, and $1.28 \mathrm{~m}$ width (divider mounting on center). Alleys between freestalls and feed bunks were $4.04 \mathrm{~m}$ wide, and alleys between freestalls and outside walls were $2.44 \mathrm{~m}$ wide. Throughout the period of the study, each of the 4 pens contained a single type of bedding material: (1) NES, which was deep-bedded, previously unused pit sand; (2) RS, which was deep-bedded sand recycled on the farm using a screw-type sand separator designed to recover 80 to $90 \%$ of sand from manure for reuse as bedding (McLanahan, Hollidaysburg, PA); (3) DBMS, which was deep-bedded manure solids recycled on the farm using a screen press; and (4) SBMS, which was the same recycled manure solids as DBMS, shallow bedded over foam-core mattresses. Twice daily while cows were milked, bedding was manually groomed and leveled in all stalls, and alleys were scraped. The base of all deep-bedded stalls consisted of approximately $20 \mathrm{~cm}$ of compacted limestone covered with approximately 30 $\mathrm{cm}$ of bedding. Immediately after bedding, the depth of noncompressed bedding (measured by inserting a ruler vertically into beds with light pressure) was 10 to $13 \mathrm{~cm}$ (NES), 10 to $15 \mathrm{~cm}$ (RS), and 7 to $13 \mathrm{~cm}$ (DBMS) with a greater depth of noncompressed bedding in the fronts of stalls with all bedding types. Stalls with mattresses and SBMS were bedded to a depth of approximately 1.5 to $3 \mathrm{~cm}$ with additional bedding in front of the brisket board drawn onto the mattresses during grooming to a maintain a depth of approximately 1.5 to $3 \mathrm{~cm}$ at the time of grooming. Fresh bedding was added to all stalls on Tuesday and Friday afternoons. All cows were fed the same TMR consisting of $20.8 \%$ corn silage, $17.5 \%$ alfalfa haylage, $5.8 \%$ alfalfa hay, $21.4 \%$ high moisture corn, $20 \%$ soybean protein mix, $5.2 \%$ corn gluten pellets, $3.6 \%$ cottonseed, and $5.8 \%$ liquid sugar and mineral mix. This barn was specifically designed to accommodate research about different lactating dairy cow bedding materials.

Weekly bedding culture and teat skin swab culture results have been previously described in Rowbotham (2015).

\section{Population of Pens and Enrollment of Quarters}

Prior to the study, all 4 pens in the newly constructed barn were populated with multiparous cows from another University of Wisconsin research facility. During 2012, before the beginning of the study, all except 15 of the multiparous cows were gradually replaced with primiparous Holsteins, which were randomly assigned to the 4 pens after parturition. Our study consisted of 2 periods. An initial sampling period (ISP) that included collection of milk samples for microbiological analysis began on January 1, 2013, and was completed on December 17, 2013. An extended observation period (EOP) that did not include collection of milk samples was conducted from December 18, 2013, until April 30, 2015. At the beginning of the ISP the initial population of cows in the pens consisted of primiparous Holsteins 
$(\mathrm{n}=96)$, multiparous cows $(\mathrm{n}=15)$, and a single primiparous Jersey (Table 1). During the study (ISP and EOP), cows exiting the facility were replaced with primiparous Holsteins $(\mathrm{n}=309)$ and some multiparous Holsteins $(\mathrm{n}=19)$ and non-Holsteins $(\mathrm{n}=9)$. Animals entered the facility after parturition and were randomly assigned to one of the 4 pens. After assignment to a bedding type, cows remained in the same pen until exiting the farm. Beginning on January 1, 2013, functioning quarters of first-lactation Holstein cows were eligible to be enrolled in this study $7 \mathrm{~d}$ after a cow entered a pen (which was also 7 DIM).

\section{Definitions}

All mastitis was defined at the quarter level. A case of CM was defined by abnormal appearance of milk, and cases were considered unique when occurring more than $14 \mathrm{~d}$ after a previous case. Clinical mastitis was detected by milking technicians by observing foremilk removed during premilking preparation. A case of SM was defined as a quarter with visually normal milk containing SCC > 200,000 cells/mL (NMC, 2001; Pantoja et al., 2009a).

Exposure of mammary quarters to bedding types was measured as quarter days at risk (QDAR), where a quarter was considered to be at risk from the date of enrollment until an incidence of SM or $\mathrm{CM}$ or until the quarter exited the study (DoHoo et al., 2012). The incidence rate of mastitis (IRM) was defined as the first cases of SM or CM per 1,000 QDAR and was calculated only for the ISP. The incidence rate of CM (IRCM) was defined as first cases of CM per 1,000 QDAR and was calculated for the combined ISP and EOP. Prevalence of SM was defined using 2 methods: (1) the number of quarters with SCC $>200,000$ cells/ $\mathrm{mL}$ divided by the total number of quarters sampled, and (2) the number of quarters with SCC >200,000 cells/mL and isolation of a pathogen divided by the number of quarters sampled.

\section{Data and Sample Collection}

During the ISP, every $28 \mathrm{~d}$ ( $\mathrm{n}=13$ sampling dates), during the morning milking, researchers collected milk samples from all enrolled quarters to determine SCC. At first sampling, cows were between 7 and 35 DIM. Quarters of cows treated for CM were not sampled. After milking was completed, milk samples were immediately transported to a nearby DHI laboratory (AgSource Milk Analysis Laboratory, Stratford, WI) and analyzed for SCC (CombiFOSS 6000, Foss Food Technology Corp., Hillerød, Denmark). Results of SCC tests were received within $4 \mathrm{~h}$. At the evening milking

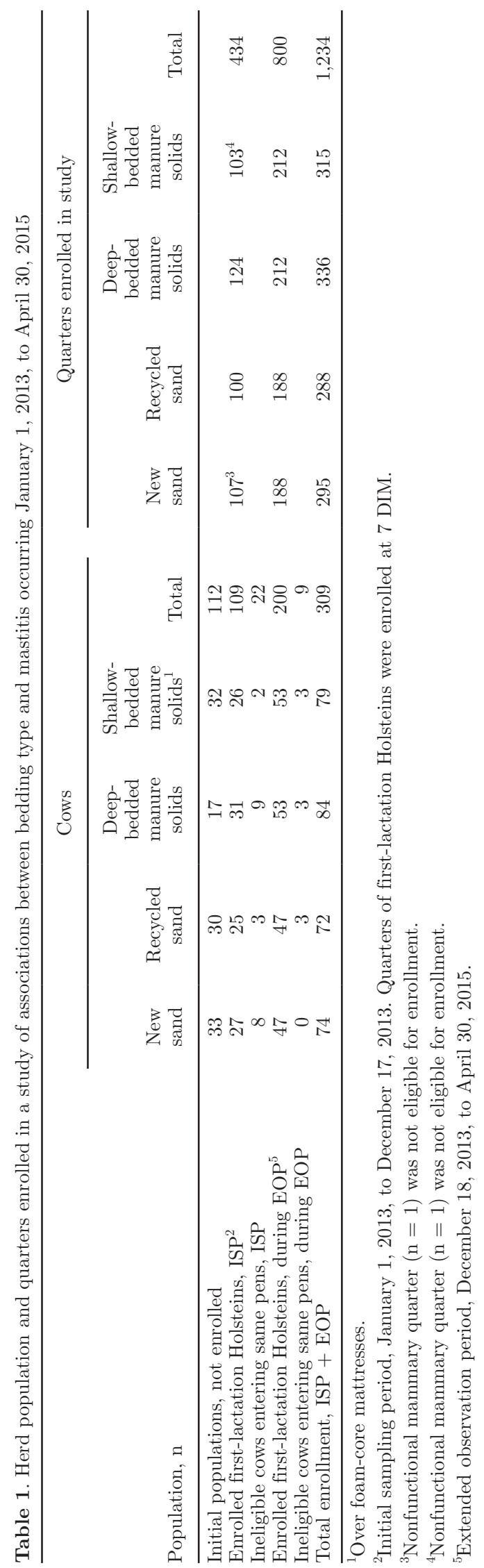

Journal of Dairy Science Vol. 99 No. 6, 2016 
of the same day, milk samples were aseptically collected from all quarters with SM (quarter-milk SCC > 200,000 cells $/ \mathrm{mL}$ ).

During each milking, milking technicians examined foremilk for abnormal milk and recorded all quarters with abnormal milk as CM. During the ISP, after detection of CM, milking technicians aseptically collected duplicate quarter milk samples that were frozen for up to $28 \mathrm{~d}$ before performing microbiological analysis at the UW Milk Quality Laboratory. During the EOP, $\mathrm{CM}$ cases were detected but milk samples were not collected.

\section{Microbial Analysis}

During the ISP, microbiological analysis of milk samples collected from quarters diagnosed with SM and CM was performed at the University of Wisconsin Milk Quality laboratory using National Mastitis Council (1999) guidelines. All but one group $(\mathrm{n}=12)$ of milk samples collected from SM were cooled and processed within $15 \mathrm{~h}$ of collection. On one occasion, due to holiday schedules, one group of aseptically collected milk samples was frozen for $28 \mathrm{~d}$ before performing microbiological analysis. Frozen milk samples were thawed at room temperature. One hundred microliters from each duplicate sample was inoculated onto one half of a trypticase soy agar plate with $5 \%$ sheep blood. Ten microliters of milk from one of the duplicate samples was inoculated onto one-quarter of a MacConkey agar plate. Plates were incubated for 24 to $48 \mathrm{~h}$ at $37^{\circ} \mathrm{C}$. Isolates that grew on MacConkey agar were inoculated on sodium citrate slants, triple sugar iron slants, motility, indole, and ornithine. Staphylococcus and Streptococcus were differentiated using catalase tests. Catalase-positive colonies were tested for mannitol and coagulase reactions. Catalase-negative colonies were tested for Christie, Atkins, Munch-Petersen (CAMP); esculin; and bilesculin reactions. Final microbiological identification was performed using a combination of biochemical tests, Gram stain characteristics, and colony morphology. An IMI was defined as the isolation of $100 \mathrm{cfu} / \mathrm{mL}$ of identical colonies with the exception of Staphylococcus aureus, for which an IMI was defined as the isolation of 10 or more $\mathrm{cfu} / \mathrm{mL}$. When 2 different types of bacteria were identified in the same milk sample, the result was classified as a mixed infection. When at least one colony of each of 3 or more different colony types was isolated from the same sample, the sample was considered contaminated. The etiology was defined using the results of duplicate milk samples based on criteria described by Pinzón-Sánchez and Ruegg (2011). Results of quarter milk samples with nonsignificant growth $(<100 \mathrm{cfu} / \mathrm{mL})$ were combined with no growth and identified as culture negative (CNEG) for analysis. Results of quarter milk samples with microbial growth were combined and identified as culture positive (CPOS) for analysis.

\section{Statistical Analysis}

Statistical analyses were performed using SAS 9.4 (SAS Institute Inc., Cary, NC). Descriptive statistics using PROC UNIVARIATE, PROC FREQ, and PROC SGPLOT were used to verify data integrity and observe distributions. Sample size calculations were performed using PROC POWER. For all multivariate models, model fit was assessed by the Akaike information criterion (Akaike, 1969). For all models, multiple comparisons were adjusted using Tukey-Kramer. All means are presented as mean $\pm \mathrm{SE}$ and significance was defined as $P \leq 0.05$.

Analysis of Cow-Level Characteristics. To test the null hypothesis that the reason for exiting the farm during the ISP, or during the combined ISP and EOP, was not associated with bedding type, 2 separate analyses using Fisher's exact test were performed using PROC FREQ. Reasons for exiting the facility included end of lactation, culled, died, or transferred to another facility. Culled, died, and transferred to another facility were combined for analysis due to sparse data. The experimental unit was cow.

To test the null hypothesis that duration in pen was not associated with bedding type, 2 univariate regression models were constructed using PROC MIXED. The explanatory variable was bedding type and the response variable was quarter days of enrollment. For the first model, quarter days of enrollment was days from enrollment to exiting the farm or the end of the ISP. For the second model, quarter days of enrollment was days from enrollment to exiting the farm or the end of the EOP. The experimental unit was mammary quarter.

To test the null hypothesis that average DHI test day DIM, SCC, and kilograms of milk produced did not differ among bedding types, 3 separate repeated measures regression models with autoregressive covariance structures were constructed using PROC MIXED. The explanatory variable in each model was bedding type and the response variables were (DIM $)^{1 / 2}$, SCS, or kilograms of milk. The experimental unit was cow.

Analysis of Quarter-Level Outcomes. To test the null hypothesis that proportions of CPOS and CNEG samples were not associated with bedding type, associations among CPOS or CNEG and bedding type were tested using a binary logit model in PROC GLIMMIX with cow as a random variable to control for quarters nested within cow, bedding type as the explanatory 
variable, and CPOS (binary) as the response variable. The experimental unit was mammary quarter nested within cow.

To test the null hypothesis that IRM during the ISP did not differ among bedding types, associations among IRM and bedding type were tested using a binary logit model in PROC GLIMMIX with cow as a random variable to control for quarters nested within cow, bedding type as the explanatory variable, and IRM as the response variable. A secondary analysis using the same model was performed for IRM with an alternative definition of SM. For the secondary analysis, SM was defined as a CPOS quarter and a SCC $>200,000$ cells/mL. Mammary quarter nested within cow was the experimental unit for both models.

To test the null hypothesis that IRCM did not differ among bedding types during the combined ISP and EOP, associations among IRCM and bedding type were tested using a binary logit model in PROC GLIMMIX with cow as a random variable to control for quarters nested within cow, bedding type as the explanatory variable, and IRCM as the response variable. The experimental unit was mammary quarter nested within cow.

To test the null hypotheses that survival until occurrence of mastitis did not differ among bedding types, survival to the first quarter-level case of mastitis stratified by bedding type was analyzed using Cox proportional hazard regression in PROC PHREG using the robust sandwich estimate option to account for clustering of quarters with cow. During the ISP, eligible quarters were included in the analysis from the time of enrollment until they left the herd (censored), or experienced an event (SM or CM). During the combined ISP and EOP, eligible quarters were included in the analysis from the time of enrollment until they left the herd (censored), or developed CM (event). The experimental unit was mammary quarter nested within cow.

Power Analysis. A priori sample size calculations were not performed because pen size and animal populations were determined by the size of the research facility. Post hoc power analysis was performed for IRM by bedding type and IRCM by bedding type.

All procedures were approved by the Animal Care and Use Committee for the College of Agricultural and Life Sciences of the University of Wisconsin-Madison.

\section{RESULTS}

\section{Quarter Enrollment}

Quarters were enrolled during the ISP $(\mathrm{n}=434)$ and the EOP $(\mathrm{n}=800)$ for a total of 1,234 quarters enrolled during the study (Table 1). Nonfunctional mammary quarters at first sampling were not eligible for enrollment ( $\mathrm{n}=1$ in NES, $\mathrm{n}=1$ in SBMS). Eligible cows with enrolled quarters were housed in the same pens as ineligible cows.

\section{Characteristics of the Cows}

Least squares means of DHI test day milk production, SCS, and DIM were not associated with bedding type $(P>0.189$; Table 2$)$. Duration of quarters in the study was associated with pen during the ISP $(P<$ $0.001)$ but not during the combined ISP and EOP $(P$ $=0.153)$. During the ISP, $80 \%(\mathrm{n}=87)$ of cows with enrolled quarters remained in the study until the end of the ISP (and continued into the EOP), 17\% $(\mathrm{n}=18)$ exited at the end of their lactation, $2 \%(\mathrm{n}=2)$ were culled, and $2 \%(\mathrm{n}=2)$ were transferred to another University of Wisconsin farm (Table 2). The proportion of cows exiting the study during the ISP due to end of lactation as compared with combined culling or transfer was not associated with bedding type $(P$ $=0.647$; Table 2). The proportion of cows exiting the study during the combined ISP and EOP due to end of lactation (as compared with combined culling, death, and transfer) was not associated with bedding type $(P$ $=0.216$; Table 2).

\section{Subclinical and Clinical Mastitis}

Subclinical Mastitis. During the ISP, 2,676 quarter-level milk samples were tested for SCC. From these quarters, milk samples were examined for microbiological growth from 66 incident cases and 69 recurrent cases of SM (Table 3). No gram-negative pathogens were recovered from milk obtained from quarters with SM. Of usable samples (not contaminated or missing) from incident cases of SM $(\mathrm{n}=59)$, the majority $(71 \%)$ were culture negative (Table 3 ). When nesting of quarters with cow was considered, the proportion of incident cases of SM $(\mathrm{n}=59)$ from usable samples that were CPOS $(\mathrm{n}=17)$ was not associated with bedding type $(P=0.202)$, and was distributed as $15 \%$ (NES; 2 of 13 ), $47 \%$ (RS; 7 of 15), 6\% (DBMS; 1 of 17), and $50 \%$ (SBMS; 7 of 14). Of usable samples obtained from recurrent cases of SM $(\mathrm{n}=64)$, the majority $(67 \%, \mathrm{n}$ $=43$ ) were CNEG (Table 3). When nesting of quarters with cow was considered, the proportion of recurrent cases of SM that were CPOS was not associated with bedding type $(P=0.476)$ and was distributed as $23 \%$ (NES; 3 of 13 ), 37\% (RS; 7 of 19), 17\% (DBMS; 3 of 18 ), and $57 \%$ (SBMS; 8 of 14 ).

Clinical Mastitis. During the ISP, 21 first cases of CM were identified from 434 quarters of 109 primiparous Holsteins. The proportion of etiologies 
Table 2. Characteristics of first-lactation Holstein cows enrolled in a study of associations between bedding type and mastitis January 1 , 2013, to April 30, 2015

\begin{tabular}{|c|c|c|c|c|c|}
\hline Item & $\begin{array}{l}\text { New } \\
\text { sand }\end{array}$ & $\begin{array}{l}\text { Recycled } \\
\text { sand }\end{array}$ & $\begin{array}{l}\text { Deep- } \\
\text { bedded } \\
\text { manure } \\
\text { solids }\end{array}$ & $\begin{array}{c}\text { Shallow- } \\
\text { bedded } \\
\text { manure } \\
\text { solids }^{1}\end{array}$ & $P$-value \\
\hline Milk per cow, kg (SE) & $33.2(1.37)$ & $30.2(1.37)$ & $30.7(1.37)$ & $30.4(1.28)$ & 0.348 \\
\hline SCS (SE) & $1.6(0.23)$ & $2.2(0.23)$ & $1.7(0.18)$ & $2.1(0.22)$ & 0.189 \\
\hline $\mathrm{DIM},{ }^{3} \mathrm{~d}(\mathrm{SE})$ & $77(20.1)$ & $80(21.6)$ & $67(14.4)$ & $59(16.6)$ & 0.782 \\
\hline Reason for exiting facility, ISP & & & & & 0.647 \\
\hline End of lactation, $\mathrm{n}$ & 4 & 4 & 9 & 1 & \\
\hline Culled, n & 0 & 0 & 1 & 1 & \\
\hline Transfer to another facility, $\mathrm{n}$ & 1 & 0 & 1 & 0 & \\
\hline Continued to EOP ${ }^{5} \mathrm{n}$ & 22 & 21 & 20 & 24 & \\
\hline Total cows (ISP), $\mathrm{n}$ & 27 & 25 & 31 & 26 & \\
\hline Total quarters (ISP), n & 107 & 100 & 124 & 103 & \\
\hline End of recording, $n$ & 33 & 29 & 31 & 34 & \\
\hline Total cows (ISP and EOP combined), $\mathrm{n}$ & 74 & 72 & 84 & 79 & \\
\hline Total quarters (ISP and EOP combined), $\mathrm{n}$ & 295 & 288 & 336 & 315 & \\
\hline
\end{tabular}

\footnotetext{
${ }^{\mathrm{a}, \mathrm{b}}$ Means with different superscripts within a row differ (Tukey adjusted $P<0.05$ ).

${ }^{1}$ Over foam-core mattresses.

${ }^{2}$ Initial sampling period, January 1, 2013, to December 17, 2013.

${ }^{3}$ DIM evaluated as $\mathrm{DIM}^{1 / 2}$ to normalize distribution and back transformed for presentation.

${ }^{4}$ Quarter days in pen. One QD in pen = exposure of one mammary quarter to bedding for $1 \mathrm{~d}$ for enrolled quarters until exiting the farm or the end of the ISP.

${ }^{5}$ Extended observation period, December 18, 2013, to April 30, 2015.
}

(gram-positive, gram-negative, CNEG) tended to be associated with bedding type (Table $3, P=0.066$ ). All 3 samples of milk obtained from cases of $\mathrm{CM}$ of cows bedded with NES were CNEG as compared with 11 to 25\% CNEG samples among other bedding types (Table 3). Almost half of milk samples from CM cases did not result in the identification of a pathogen [CNEG $(\mathrm{n}=$ $6)$, contaminated $(\mathrm{n}=5)]$.

During the combined ISP and EOP, 1,234 enrolled quarters from 309 first-lactation Holsteins were monitored. Of these, 73 quarters experienced 1 case of CM, 16 experienced 2 cases, and 2 experienced 3 cases. The overall IRCM was 0.26 cases/1,000 QDAR and IRCM was not associated with bedding types $(P=0.193$; Table 4). There were tendencies for differences in survival times among bedding types $(P=0.071)$. When adjusted for multiple comparisons, there was a tendency for longer survival times to first case of $\mathrm{CM}$ for quarters of cows in pens containing NES as compared with quarters of cows bedded with $\mathrm{RS}(P=0.056)$ or DBMS $(P=0.086)$.

Overall Incidence Rate of Mastitis. During the ISP, 84 first cases of mastitis (SM or CM) were recorded. The number of first cases of mastitis is less than the sum of first cases of SM and first cases of CM (Table 3 ) due to 3 quarters (1 each in NES, DBMS, and SBMS) that experienced both CM and SM. The overall IRM during the ISP was 1.36 cases/1,000 QDAR and was not associated with bedding type $(P=0.527$; Table 5 ). The overall IRM from the secondary analysis (with SM defined as a CPOS quarter with SCC >200,000 cells $/ \mathrm{mL}$ ) was 0.29 cases/1,000 QDAR. In this analysis, the IRM for quarters of cows in pens containing SBMS (0.66 cases/1,000 QDAR) and RS 0.44 cases/1,000 QDAR) were greater than the IRM for quarters of cows bedded with NES (0.14 cases/1,000 QDAR) or DBMS (0.05 cases/1,000 QDAR). Using the primary definition of SM (SCC >200,000 cells $/ \mathrm{mL}$ ), there were no differences in survival times to first case of $\mathrm{CM}(P=0.169)$ among bedding types.

\section{Power Analysis}

For analyses where no difference was observed, sample size in this study provided an excess of $95 \%$ confidence and $80 \%$ power to detect a difference in IRM by bedding type of 2.13 cases/1,000 QDAR, and IRCM by bedding type of 1.48 cases/1,000 QDAR. 
Table 3. Results of microbiological analysis of milk samples obtained from enrolled quarters $(\mathrm{n}=434)$ with SCC $>200,000$ cells $/ \mathrm{mL}$ or first cases of clinical mastitis $(\mathrm{CM})$ in a study of first-lactation Holsteins $(\mathrm{n}=109)$ housed on 4 different beddings from January 1, 2013, to December 17,2013

\begin{tabular}{|c|c|c|c|c|c|c|}
\hline \multirow[b]{2}{*}{ Isolate, n } & \multicolumn{4}{|c|}{ Bedding } & \multirow[b]{2}{*}{ Total } & \multirow[b]{2}{*}{ Results, ${ }^{2} \%$} \\
\hline & $\begin{array}{l}\text { New } \\
\text { sand }\end{array}$ & $\begin{array}{c}\text { Recycled } \\
\text { sand }\end{array}$ & $\begin{array}{l}\text { Deep- } \\
\text { bedded } \\
\text { manure } \\
\text { solids }\end{array}$ & $\begin{array}{l}\text { Shallow- } \\
\text { bedded } \\
\text { manure } \\
\text { solids }^{1}\end{array}$ & & \\
\hline Microbiological results of incident cases of $\mathrm{SM}^{3,4,5}$ & 13 & 17 & 18 & 18 & 66 & \\
\hline CNS & 1 & 6 & 1 & 6 & 14 & 23.7 \\
\hline Environmental Streptococcus spp. & 1 & 0 & 0 & 0 & 1 & 1.7 \\
\hline Corynebacterium spp. & 0 & 1 & 0 & 0 & 1 & 1.7 \\
\hline Staphylococcus aureus & 0 & 0 & 0 & 1 & 1 & 1.7 \\
\hline Nonsignificant growth & 11 & 8 & 16 & 7 & 42 & 71.2 \\
\hline No sample & 0 & 1 & 0 & 3 & 4 & \\
\hline Contaminated & 0 & 1 & 1 & 1 & 3 & \\
\hline Microbiological results of recurrent cases of $\mathrm{SM}^{6,7}$ & 14 & 19 & 19 & 17 & 69 & \\
\hline CNS & 2 & 7 & 3 & 7 & 19 & 29.7 \\
\hline Environmental Streptococcus spp. & 1 & 0 & 0 & 0 & 1 & 1.6 \\
\hline Staphylococcus aureus & 0 & 0 & 0 & 1 & 1 & 1.6 \\
\hline Nonsignificant growth & 10 & 12 & 15 & 6 & 43 & 67.2 \\
\hline Contaminated & 1 & 0 & 1 & 3 & 5 & \\
\hline Microbiological results from incident case of $\mathrm{CM}^{8}$ & 3 & 9 & 5 & 4 & 21 & \\
\hline CNS & 0 & 2 & 0 & 1 & 3 & 18.8 \\
\hline Environmental Streptococcus spp. & 0 & 1 & 0 & 0 & 1 & 6.3 \\
\hline Staphylococcus aureus & 0 & 0 & 0 & 1 & 1 & 6.3 \\
\hline Escherichia coli & 0 & 0 & 3 & 0 & 3 & 18.8 \\
\hline Klebsiella spp. & 0 & 1 & 0 & 0 & 1 & 6.3 \\
\hline Yeast & 0 & 1 & 0 & 0 & 1 & 6.3 \\
\hline No or nonsignificant growth & 3 & 1 & 1 & 1 & 6 & 37.5 \\
\hline Contaminated & - & 3 & 1 & 1 & 5 & \\
\hline
\end{tabular}

${ }^{1}$ Over foam core mattresses.

${ }^{2}$ Of usable samples.

${ }^{3}$ Subclinical mastitis defined as a quarter with $\mathrm{SCC}>200,000$ cells $/ \mathrm{mL}$.

${ }^{4}$ Usable samples: new sand $(\mathrm{n}=13)$, recycled sand $(\mathrm{n}=15)$, deep-bedded manure solids $(\mathrm{n}=17)$, shallow-bedded manure solids $(\mathrm{n}=14)$.

${ }^{5}$ Culture positive samples: new sand $(\mathrm{n}=2)$, recycled sand $(\mathrm{n}=7)$, deep-bedded manure solids $(\mathrm{n}=1)$, shallow-bedded manure solids $(\mathrm{n}=7)$. ${ }^{6}$ Usable samples: new sand $(\mathrm{n}=13)$, recycled sand $(\mathrm{n}=19)$, deep-bedded manure solids $(\mathrm{n}=18)$, shallow-bedded manure solids $(\mathrm{n}=14)$.

${ }^{7}$ Culture positive samples: new sand $(\mathrm{n}=3)$, recycled sand $(\mathrm{n}=7)$, deep-bedded manure solids $(\mathrm{n}=3)$, shallow-bedded manure solids $(\mathrm{n}=8)$.

${ }^{8}$ Clinical mastitis defined as abnormal appearance of milk.

\section{DISCUSSION}

Environmental mastitis is a multifactorial disease with risk factors associated with the environment and the bovine immune system. Environmental factors include cow hygiene (Schreiner and Ruegg, 2003), premilking routine (Pankey, 1989), and the number of pathogens on the teat end (Neave et al., 1966; Pankey, 1989). Due to

Table 4. Clinical mastitis (CM) incidence rates in a study of 1,234 quarters in 309 first-lactation Holsteins housed on 4 different beddings during the combined intensive sampling period and extended observation period (January 1, 2013, to April 30, 2015)

\begin{tabular}{|c|c|c|c|c|c|}
\hline Bedding & Quarters, ${ }^{1} \mathrm{n}$ & $\begin{array}{l}\mathrm{QDAR}^{2} \\
\mathrm{n} / 1,000\end{array}$ & CM cases, $n$ & $\begin{array}{c}\text { Incidence rate, } \\
\mathrm{CM} / 1,000 \text { QDAR }\end{array}$ & $\begin{array}{l}\text { Type III } \\
P \text {-value }\end{array}$ \\
\hline Deep-bedded new sand & 295 & 71.753 & 9 & 0.13 & 0.193 \\
\hline Deep-bedded recycled sand & 288 & 65.550 & 22 & 0.34 & \\
\hline Shallow-bedded manure solids ${ }^{3}$ & 315 & 69.148 & 19 & 0.28 & \\
\hline Total & 1,234 & 281.203 & 73 & 0.26 & \\
\hline
\end{tabular}

${ }^{1}$ Enrolled mammary quarters.

${ }^{2}$ Quarter days at risk. One QDAR = exposure of one enrolled mammary quarter to bedding for $1 \mathrm{~d}$ before a case of CM during the extended sampling period.

${ }^{3}$ Over foam-core mattresses. 
Table 5. Overall, mastitis incidence rates of subclinical (SM) and clinical mastitis (CM) in a study of 434 quarters of 109 primiparous cows housed on 4 different bedding types during the intensive sampling period (January 1 to December 17, 2013)

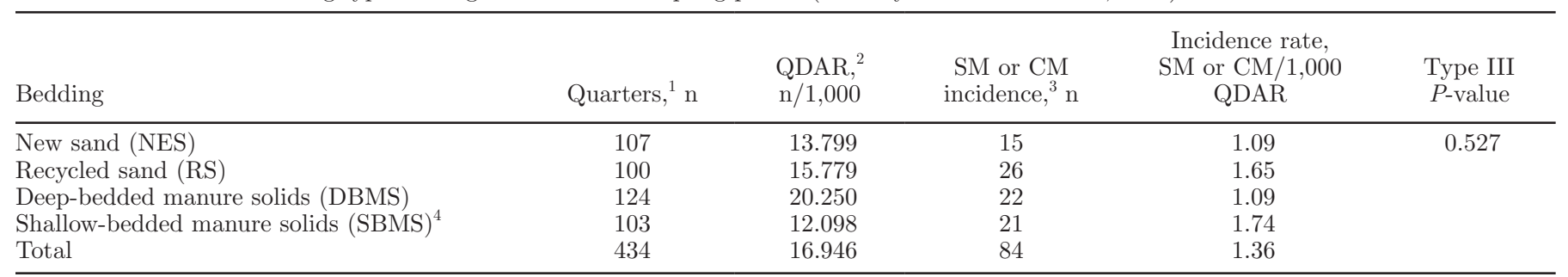

${ }^{1}$ Enrolled mammary quarters.

${ }^{2}$ Quarter days at risk. One QDAR = exposure of one enrolled mammary quarter to bedding for $1 \mathrm{~d}$ before first case of mastitis during the intensive sampling period.

${ }^{3}$ Total SM or CM incidence $(\mathrm{n}=84)$ is greater than incidence of SCC $>200,000$ cells $/ \mathrm{mL}$ in Table $3(\mathrm{n}=66)$ due to $2,8,3$, and 5 cases of CM in quarters with no cases of SM in quarters of cows bedded with NES, RS, DBMS, and SBMS, respectively. Total SM or CM incidence ( $\mathrm{n}=$ $84)$ is less than sum of first cases of SCC $>200,000$ cells $/ \mathrm{mL}$ in Table $3(\mathrm{n}=87)$ and first cases of CM in Table 3 ( $\mathrm{n}=21)$ due to 3 quarters $(1$ each in NES, DBMS, and SBMS) that experienced both CM and SM.

${ }^{4}$ Over foam core mattresses.

the complexity of environmental mastitis, we conducted our study in a single research facility specifically designed to study the effect of different bedding materials on animal management (USDA-ARS, 2011). With the exception of bedding type, the facility provided uniform feed, management, milking, and housing, which allowed researchers better control of variation within the study. The use of a single facility also allowed researchers to use consistent bedding materials throughout the study. To the best of our knowledge, this is the first study to use a single facility containing randomly assigned cows to study the association of different bedding types with incidence of SM and CM. The use of a research herd also allowed lactating cows to remain in a single pen throughout an entire lactation, a practice which would not be practical on most commercial dairies. In many controlled experiments, treatments (such as different diets) are applied to pens of animals and the pen is considered to be the experimental unit. In those studies, the use of replicated pens allows for determination of effects of the specific treatment on the outcome variable of interest. The design of this observational study was unique because the pen itself was the treatment (bedding was indistinguishable from pen), and thus we were able to use mammary quarter nested within cow as the experimental unit. In this type of observational study, associations (rather than causality) between the risk factor (in this instance, pen containing a particular bedding type) and the outcome (SM and CM) are determined. Clustering of quarter within cow was accounted for by including cow as a random variable in PROC GLIMMIX and using the robust sandwich estimate option with PROC PHREG. A limitation of using a single facility with cows remaining the same treatment pens for their entire lactation is the lack of replication. Even with pens designed and constructed to identical specifications, without replication, pen is completely indistinguishable from treatment.

Cows in our study were housed in freestalls similar to those used to house cows on many commercial dairy farms in the United States. Dairy farms in the United States containing 100 to 499 cows and $\geq 500$ cows use freestall housing for $23 \%$ and $63 \%$ of lactating cows, respectively (USDA-NASS, 2014b). Larger Wisconsin dairy farms almost exclusively (99.6\% of farms) use freestall barns to house lactating cows (Rowbotham and Ruegg, 2015). Even though all enrolled cows were primiparous, milk production was similar to US milk production $(32.5 \mathrm{~kg} / \mathrm{d})$, indicating that nutritional management and genetic potential of the research herd were similar to commercial dairy operations (USDANASS, 2014a). As this facility is adjacent to the University of Wisconsin heifer raising facility and contains mostly primiparous Holsteins, the reference population for this study is primiparous Holsteins housed in freestall barns and results should not be extrapolated to multiparous cows. Unbeknownst to the investigators, farm staff did not evenly allocate the few multiparous cows that were also assigned to this facility and the pen containing SBMS did not contain multiparous cows. At the beginning of the ISP, multiparous cows $(\mathrm{n}=15)$ were distributed among NES $(\mathrm{n}=5), \operatorname{RS}(\mathrm{n}=5)$, and DBMS $(\mathrm{n}=5)$. During the ISP, multiparous cows $(\mathrm{n}=17)$ entered the NES $(\mathrm{n}=7), \operatorname{RS}(\mathrm{n}=3)$, and DBMS $(\mathrm{n}=7)$ pens. Although it is unfortunate that the multiparous cows were not evenly distributed, the presence of multiparous cows in pens was unlikely to have influenced the results. The outcomes of culturing milk from SCM were primarily no-growth and CNS, whereas almost all milk samples obtained from cases of CM were environmental pathogens such as Escherichia coli and CNS. Staphylococcus aureus was recovered 
from 1 quarter ( 2 cases) of 1 cow that was located in the pen containing SBMS, which was the only pen not containing multiparous cows.

Mammary quarters that are free of infection usually have low SCC $(<200,000$ cells/mL; NMC, 2001). For our primary analysis, we defined SM as a quarter with a SCC >200,000 cells $/ \mathrm{mL}$ and did not require isolation of a pathogen. The use of this definition allowed us to identify quarters with inflammation that had experienced spontaneous clearance of the pathogen (self-cures; Oliveira et al., 2013), and quarters that remained infected but the number of colonies was below our limit of detection (or could not be grown using our culture methods). We also performed a secondary analysis using an alternative definition of SM that required isolation of a presumed pathogen. Although statistical differences were present among IRM, using the alternative definition resulted in very few cases of SM $(2,7$, 1, and 8 quarters with SM for cows in pens with NES, RS, DBMS, and SBMS, respectively). On a practical basis, SM is normally defined based on SCC and for our primary analysis we used our initial definition that was based solely on quarter SCC $>200,000$ cells $/ \mathrm{mL}$. A previous study of foremilk samples from 22,467 quarters of 554 cows from 7 herds with bulk milk SCC $<150,000$ cells $/ \mathrm{mL}$ reported sensitivity of $74.5 \%$ and specificity of $89.6 \%$ for detecting IMI at 200,000 cells/mL with IMI defined as isolation of the same pathogen from a mammary quarter in both of 2 duplicate samples (Schepers et al., 1997). Using our SCC threshold, at the risk of not finding $25 \%$ of potentially infected quarters, $90 \%$ of healthy quarters were not sampled for microbiological analysis. The sensitivity of our methodology may have been greater than $75 \%$ because isolation of a pathogen from one of 2 duplicate samples was considered as CPOS. For samples obtained from quarters with CM, our proportion of CNEG samples $(38 \%)$ was similar to results of previous studies using milk samples obtained from cows on large Wisconsin herds (Pinzón-Sánchez and Ruegg, 2011; Oliveira et al., 2013).

Our primary definition of quarter level SM (SCC $>200,000$ cells $/ \mathrm{mL}$ ) at first sampling with 28 -d sampling intervals dictated that cows were between 7 and $35 \mathrm{DIM}$ at the first sampling of their quarters. It is possible that a quarter could have had a case of SM before parturition and entering a treatment groups. This risk would have been evenly distributed among treatments because cows and quarters were evenly distributed across treatment groups. This risk was also low due to very few mastitis cases as indicated by low incident rates of subclinical mastitis.

Bacterial populations in the bedding and on teat skin of cows in this study have been previously described (Rowbotham, 2015). Briefly, large numbers of strepto- cocci were recovered from all bedding types in all seasons with the greatest numbers in SBMS and least in NES and DBMS. Large numbers of streptococci were also recovered from teats of cows on all bedding types with greatest numbers recovered from teats of cows bedded with SBMS and RS, intermediate numbers for teats of cows bedded with NES, and least numbers for teats of cows bedded with DBMS. Streptococci and other gram-positive bacteria are normally associated with IMI characterized by long duration subclinical stages that occasionally result in CM (Todhunter et al., 1995; Zadoks, et al., 2003). The proportion of CPOS samples from first cases of SM was less for quarters of cows bedded with NES $(15 \%)$ or DBMS $(6 \%)$ as compared with quarters of cows bedded with RS (47\%) or SBMS (50\%). These findings correspond to least numbers of streptococci recovered from teats of cows bedded with NES and DBMS (Rowbotham, 2015), indicating that lesser proportions of CPOS samples were from quarters of cows bedded with the materials which exposed teats to fewest potential gram-positive mastitis pathogens. Although we did not observe a difference in survival to incident case of mastitis among bedding types, our sample size was insufficient to detect small differences due to low incidence rates of both SM and CM.

Isolates from CPOS milk samples obtained from cows enrolled in our study were distributed as gram-negative (40\%), gram-positive (50\%), and yeast (10\%), similar to results from recent studies characterizing $\mathrm{CM}$ on large Wisconsin dairy herds (Pinzón-Sánchez and Ruegg, 2011; Oliveira et al., 2013). With the exception of a single Staphylococcus aureus isolate, pathogens isolated from CM cases in our study were all of environmental origin. Environmental streptococcus, Escherichia coli, and Klebsiella spp. were identified in $50 \%$ of culture positive cases of CM and were among bacteria cultured from bedding and teat swab samples (Rowbotham, 2015).

During our study, no cases of SM were associated with gram-negative pathogens. In contrast to streptococci, which usually cause SM with a long duration subclinical phase, gram-negative pathogens are normally associated with short duration infections that often result in clinical signs (Smith et al., 1985; Hogan and Smith, 2003). Based on results of cultures of bedding in the pens (Rowbotham, 2015), total gram-negative, coliform, and Klebsiella spp. numbers were greatest in DBMS, intermediate in SBMS and RS, and least in NES. Fewest numbers of total gram-negative bacteria were recovered from teats of cows bedded with NES as compared with other bedding types, and meaningful numbers of coliform and Klebsiella spp. were only recovered from teat skin of cows bedded with DBMS (Rowbotham, 2015). Despite the small number of mas- 
titis events observed in our study, we found tendencies for longer survival to first case of CM for quarters of cows bedded with NES than with RS or DBMS. This association corresponds with fewest numbers of gram-negative bacteria in NES. Our power calculations indicated that sample size was only sufficient to detect a difference of 1.48 cases/1,000 QDAR for IRCM. Our overall IRCM was 0.26 cases/1,000 QDAR and differences among IRCM for various bedding types ranging from 0.03 to 0.21 cases/1,000 QDAR. While IRCM for cows bedded with NES is approximately 3 times less than the IRCM for cows bedded with other materials, due to our low incidence rates, we do not know if this difference is associated with bedding or the result of random chance.

Our reference population was primiparous Holsteins housed in freestall barns and is not characteristic of cows in commercial dairy farms; however, $35.2 \%$ of all cows on US dairy farms were primiparous (Hare et al., 2006). The overall IRCM experienced in this herd was lower than previous studies (Olde Riekerink et al., 2008; Santman-Berends et al., 2015), likely due to the large proportion of primiparous cows. During the ISP, we were not able to detect an association of IRM with bedding type; however, our overall IRM was only 1.36 cases /1,000 QDAR and our ability to detect differences in IRM was 2.13 cases/1,000 QDAR. A recent review reported previous studies identifying prevalence of quarter-level SM in early lactation heifers ranging from 12 to 58\% (De Vliegher et al., 2012). Prevalence of SM during our study of $5.2 \%$ measured as quarters with SCC $>200,000$ cells $/ \mathrm{mL}$ or $2.6 \%$ measured as quarters with SCC >200,000 cells/mL and isolation of a pathogen (also measured at the quarter level) was much less than results of earlier studies. Previous research indicates that both CM and SM occur more frequently in multiparous cows (Barkema et al., 1998; Busato et al., 2000) and reinforce that our results apply specifically to primiparous animals. The influence of bedding type as a reservoir for mastitis pathogens may be more important for second and later lactation cows than for the first-lactation cows included in this study because multiparous cows are more susceptible to both SM and $\mathrm{CM}$ and because after a cow has experienced a case of $\mathrm{CM}$, she is more likely to experience a case later in the same or in future lactations (Pantoja et al., 2009a,b; Pinzón-Sánchez and Ruegg, 2011). Primiparous dairy cows are known to have a lower risk of both SM and $\mathrm{CM}$ and may be able to withstand greater exposure to environmental bacteria. Thus, farmers may have an opportunity to selectively use organic bedding materials in pens that contain only primiparous cows without negatively affecting udder health.
New sand has been identified as an ideal bedding for dairy cattle (Hogan and Smith, 2012). Farmers have shown interest in recycling sand on-farm to use as bedding (Kristula et al., 2005) or using recycled manure as bedding to reduce sand purchase expenses and reduce the total tons of DM in the manure stream (Godden et al., 2008; Husfeldt and Endres, 2012). Bacterial populations representing potential mastitis pathogens were least in NES and least on teats of cows bedded with NES (gram-negative, coliform, Klebsiella spp.) or on teats of cows bedded with DBMS and NES (streptococci; Rowbotham, 2015). In our study, despite relatively few mastitis events, survival time to incidence of CM tended to be longer for primiparous cows bedded with NES as compared with primiparous cows bedded with RS or DBMS, but was similar to primiparous cows housed in pens containing SBMS. Overall, our results agree with earlier results of lesser rates of $\mathrm{CM}$ among cows on farms using inorganic bedding than on farms using organic bedding (Hogan et al., 1989), but also indicate that organic bedding materials may pose less risk as a bedding source for primiparous cows.

\section{CONCLUSIONS}

The proportion of SM samples that were CNEG was numerically greater in quarters of primiparous cows bedded with NES and DBMS as compared with those bedded with RS and SBMS. A tendency was observed for a lesser IRCM for quarters of primiparous cows bedded with NES as compared with cows on other bedding types, and survival time to first case of CM was greater for quarters of primiparous cows bedded with NES than RS or DBMS despite the occurrence of few cases of CM during the study. Correspondingly, far fewer cases of CM were caused by gram-negative bacteria for primiparous cows housed in pens containing NES than in other bedding types. The relationships of longest survival time to incidence of CM and numerically fewest CPOS samples from quarters of primiparous cows bedded with NES reinforces the advantages of bedding with NES for our reference population of primiparous Holsteins.

\section{ACKNOWLEDGMENTS}

The authors thank the USDA Agricultural Research Service for the use of their facilities, the University of Wisconsin-Madison for the use of their dairy herd, the dairy farm personnel at the Marshfield Agricultural Research Station for their participation in this project, and the Grande Cheese Company for project funding. 


\section{REFERENCES}

Akaike, H. 1969. Fitting autoregressive models for prediction. Ann. Inst. Stat. Math. 21:243-247.

Barkema, H. W., Y. H. Schukken, T. J. G. M. Lam, M. L. Beiboer, H. Wilmink, G. Benedictus, and A. Brand. 1998. Incidence of clinical mastitis in dairy herds grouped in three categories by bulk milk somatic cell counts. J. Dairy Sci. 81:411-419.

Busato, A., P. Trachsel, M. Schällibaum, and J. W. Blum. 2000. Udder health and risk factors for subclinical mastitis in organic dairy farms in Switzerland. Prev. Vet. Med. 44:205-220.

Cook, N. B., T. B. Bennett, and K. V. Nordlund. 2005. Monitoring indices of cow comfort in free-stall-housed dairy herds. J. Dairy Sci. 88:3876-3885

De Vliegher, S., L. K. Fox, S. Piepers, S. McDougall, and H. W. Barkema. 2012. Invited review: Mastitis in dairy heifers: Nature of the disease, potential impact, prevention, and control. J. Dairy Sci. 95:1025-1040.

DoHoo, I., W. Martin, and H. Stryhn. 2012. Methods in Epidemiologic Research. Ver. Inc., Charlottetown, Prince Edward Island, Canada.

Fairchild, T. P., B. J. McArthur, J. H. Moore, and W. E. Hylton. 1982. Coliform counts in various bedding materials. J. Dairy Sci. 65:1029-1035.

Godden, S., R. Bey, K. Lorch, R. Farnsworth, and P. Rapnicki. 2008. Ability of organic and inorganic bedding materials to promote growth of environmental bacteria. J. Dairy Sci. 91:151-159.

Hare, E., H. D. Norman, and J. R. Wright. 2006. Survival rates and productive herd life of dairy cattle in the United States. J. Dairy Sci. 89:3713-3720.

Hogan, J., and K. L. Smith. 2003. Coliform mastitis. Vet. Res. 34:507519.

Hogan, J., and K. L. Smith. 2012. Managing environmental mastitis. Vet. Clin. North Am. Food Anim. Pract. 28:217-224.

Hogan, J. S., K. L. Smith, K. H. Hoblet, D. A. Todhunter, P. S. Schoenberger, W. D. Hueston, D. E. Pritchard, G. L. Bowman, L. E. Heider, B. L. Brockett, and H. R. Conrad. 1989. Bacterial counts in bedding materials used on nine commercial dairies. J. Dairy Sci. $72: 250-258$.

Husfeldt, A. W., and M. I. Endres. 2012. Association between stall surface and some animal welfare measurements in freestall dairy herds using recycled manure solids for bedding. J. Dairy Sci. 95:5626-5634.

Janzen, J. J., R. R. Bishop, A. B. Bodine, C. A. Caldwell, and D. W. Johnson. 1982. Composted dairy waste solids and crushed limestone as bedding in free stalls. J. Dairy Sci. 65:1025-1028.

Kristula, M. A., W. Rogers, J. S. Hogan, and M. Sabo. 2005. Comparison of bacteria populations within clean and recycled sand used for bedding in dairy facilities. J. Dairy Sci. 88:4317-4325.

Lago, A., S. M. Godden, R. Bey, P. L. Ruegg, and K. Leslie. 2011. The selective treatment of clinical mastitis based on on-farm culture results: I. Effects on antibiotic use, milk withholding time, and short-term clinical and bacteriological outcomes. J. Dairy Sci. 94:4441-4456.

National Mastitis Council. 1999. Laboratory Handbook on Bovine Mastitis. National Mastitis Council, Verona, WI.

National Mastitis Council. 2001. Guidelines on normal and abnormal raw milk based on somatic cell counts and signs of clinical mastitis. Accessed Oct. 6, 2015. https://nmconline.org/docs/abnmilk.pdf.

Natzke, R. P., and B. J. LeClair. 1976. Coliform contaminated bedding and new infections. J. Dairy Sci. 59:2152-2154.

Neave, F. K., F. H. Dodd, and R. G. Kingwill. 1966. A method on controlling udder disease. Vet. Rec. 78:521-523.
Olde Riekerink, R. G. M., H. W. Barkema, D. F. Kelton, and D. T. Scholl. 2008. Incidence rate of clinical mastitis on Canadian dairy farms. J. Dairy Sci. 91:1366-1377.

Oliveira, L., C. Hulland, and P. L. Ruegg. 2013. Characterization of clinical mastitis occurring in cows on 50 large dairy herds in Wisconsin. J. Dairy Sci. 96:7538-7549.

Pankey, J. W. 1989. Premilking udder hygiene. J. Dairy Sci. 72:13081312.

Pantoja, J. C. F., C. Hulland, and P. L. Ruegg. 2009a. Somatic cell count status across the dry period as a risk factor for the development of clinical mastitis in the subsequent lactation. J. Dairy Sci. 92:139-148.

Pantoja, J. C. F., C. Hulland, and P. L. Ruegg. 2009b. Dynamics of somatic cell counts and intramammary infections across the dry period. Prev. Vet. Med. 90:43-54.

Pinzón-Sánchez, C., and P. L. Ruegg. 2011. Risk factors associated with short-term post-treatment outcomes of clinical mastitis. J. Dairy Sci. 94:3397-3410.

Rendos, J. J., R. J. Eberhart, and E. M. Kesler. 1975. Microbialpopulations of teat ends of dairy-cows, and bedding materials. J. Dairy Sci. 58:1492-1500.

Rowbotham, R. F. 2015. Associations between dairy cow bedding and milk quality. PhD Thesis. University of Wisconsin, Madison.

Rowbotham, R. F., and P. L. Ruegg. 2015. Association of bedding types with management practices and indicators of milk quality on larger Wisconsin dairy farms. J. Dairy Sci. 98:7865-7885.

Santman-Berends, I. M. G. A., T. J. G. M. Lam, J. Keurentjes, and G. van Schaik. 2015. An estimation of the clinical mastitis incidence per 100 cows per year based on routinely collected herd data. J. Dairy Sci. 98:6965-6977.

Schepers, A. J., T. J. G. M. Lam, Y. H. Schukken, J. B. M. Wilmink, and W. J. A. Hanekamp. 1997. Estimation of variance components for somatic cell counts to determine thresholds for uninfected quarters. J. Dairy Sci. 80:1833-1840.

Schreiner, D. A., and P. L. Ruegg. 2003. Relationship between udder and leg hygiene scores and subclinical mastitis. J. Dairy Sci. 86:3460-3465.

Smith, K. L., D. A. Todhunter, and P. S. Schoenberger. 1985. Symposium: Environmental effects on cow health and performance. J. Dairy Sci. 68:1531-1553.

Todhunter, D. A., K. L. Smith, and J. S. Hogan. 1995. Environmental streptococcal intramammary infections of the bovine mammary gland. J. Dairy Sci. 78:2366-2374.

Tucker, C. B., and D. M. Weary. 2004. Bedding on geotextile mattresses: How much is needed to improve cow comfort? J. Dairy Sci. 87:2889-2895.

USDA-ARS. 2011. Assessment of new sand vs. recycled products of manure separation as bedding materials for lactating cows in freestall housing. Project number: 5090-12630-003-06. Accessed Oct. 4, 2015. http://www.ars.usda.gov/research/projects/projects. htm?accn $\_n o=421662$.

USDA-NASS. 2014a. Milk Production. ISSN: 1949-1557 Released February 20, 2014. Accessed Mar. 17, 2015. https://usda.mannlib. cornell.edu/MannUsda/viewDocumentInfo.do?documentID=1103.

USDA-NASS. 2014b. Quick Stats Tools. Accessed Apr. 29, 2014. http://www.nass.usda.gov/Quick_Stats/.

Zadoks, R. N., B. E. Gillespie, H. W. Barkema, O. C. Sampimon, S. P. Oliver, and Y. H. Schukken. 2003. Clinical, epidemiological and molecular characteristics of Streptococcus uberis infections in dairy herds. Epidemiol. Infect. 130:335-349.

Zdanowicz, M., J. A. Shelford, C. B. Tucker, D. M. Weary, and M. A. G. von Keyserlingk. 2004. Bacterial populations on teat ends of dairy cows housed in free stalls and bedded with either sand or sawdust. J. Dairy Sci. 87:1694-1701. 